\title{
Allogeneic hematopoietic stem cell transplantation in two brothers with DNA ligase IV deficiency: a case report and review of the literature
}

Sarah Schober ${ }^{1}$, Karin Schilbach ${ }^{1}$, Michaela Doering ${ }^{1}$, Karin M. Cabanillas Stanchi', Ursula Holzer ${ }^{1}$, Patrick Kasteleiner ${ }^{1}$, Jens Schittenhelm², Juergen F. Schaefer ${ }^{3}$, Ingo Mueller ${ }^{4}$, Peter Lang ${ }^{1}$ and Rupert Handgretinger ${ }^{1 *}$

\begin{abstract}
Background: DNA ligase IV deficiency is a rare autosomal recessive disorder caused by hypomorphic mutations in the DNA ligase IV (LIG4) gene. DNA ligase IV is an essential protein for the development of a healthy immune system as well as for the protection of genomic integrity. Apart from typical stigmata, patients with DNA ligase IV deficiency are characterized by progressive bone marrow failure and a predisposition to malignancy. To our knowledge this reported case is the first description of two brothers with ligase IV deficiency who are treated with different hematopoietic stem cell transplantation (HSCT) regimens resulting in vastly divergent outcomes.

Case presentation: The cases of two brothers suffering from severe recurrent infections and growth retardation are described. The laboratory findings showed pancytopenia with significant lymphopenia. The two boys were diagnosed with DNA ligase IV deficiency, associated with severe combined immunodeficiency (SCID). Both patients received HSCT from two different matched unrelated donors (MUD) at the age of 33 and 18 months. The older brother succumbed post-transplant due to fatal side-effects 143 days after allogeneic HSCT. The younger brother conditioned with a different regimen - received a T cell depleted graft 4 months later. No severe side-effects occurred, neither post-transplant nor in the following years. Ten years after HSCT the patient is well off, living a normal life and attending a regular high school. His immune system is fully reconstituted, resulting in a maximum of T cell receptor (TCR) diversity, which is a prerequisite for immune competence. However, he still suffers from microcephaly, dwarfism and dystrophy.

Conclusions: This case report gives an example of a successful HSCT as a treatment option in a genetic disorder such as ligase IV deficiency, using a rather mild conditioning regimen. Further studies are required to determine the viability and efficacy of this treatment option.
\end{abstract}

Keywords: DNA ligase IV deficiency, LIG4, Severe combined immunodeficiency, SCID, Steroid-refractory graft-versushost disease, GVHD, Conditioning regimen, Hematopoietic stem cell transplantation, HSCT, Cyclosporine A

\footnotetext{
* Correspondence: Rupert.handgretinger@med.uni-tuebingen.de

'Department I - General Pediatrics, Hematology/Oncology, University

Children's Hospital Tuebingen, Hoppe-Seyler-Str.1, 72076 Tuebingen,

Germany

Full list of author information is available at the end of the article
}

(c) The Author(s). 2019 Open Access This article is distributed under the terms of the Creative Commons Attribution 4.0 International License (http://creativecommons.org/licenses/by/4.0/), which permits unrestricted use, distribution, and reproduction in any medium, provided you give appropriate credit to the original author(s) and the source, provide a link to the Creative Commons license, and indicate if changes were made. The Creative Commons Public Domain Dedication waiver (http://creativecommons.org/publicdomain/zero/1.0/) applies to the data made available in this article, unless otherwise stated. 


\section{Background}

DNA ligase IV deficiency is a rare form of autosomal recessive, radiosensitive severe combined immunodeficiency (SCID), which is caused by hypomorphic mutations of the DNA ligase IV (LIG4) gene. The disorder was first described in 1999 [1]. Less than 45 cases have been reported worldwide [2-8]. Considering the number of published descriptions of asymptomatic patients with DNA ligase IV mutations, there might be an indefinite number of unreported cases [5]. The clinical manifestation varies from asymptomatic mutation carrier status to severe immunodeficiency with life-threatening infections and lethal malignancies $[3,5,8]$.

Typical clinical features are microcephaly, growth retardation beginning in utero, typical facial appearance ("bird-like face" with sloping forehead, micrognathia, long nose), developmental and mental delay [9], combined immunodeficiency, pancytopenia due to bone marrow failure (70\% of all cases reported), clinical and cellular hypersensitivity to ionizing radiation and a predisposition to malignancy (25\% of all cases reported, especially leukemia and lymphoma) $[3,8,10]$. Bony deformations and skin conditions have also been reported [11]. These symptoms show high clinical variability.

DNA ligase IV is a key component in the repair of DNA double-strand breaks by the non-homologous end-joining (NHEJ) pathway. This pathway is also required for generation of $\mathrm{T}$ and $\mathrm{B}$ cell receptors and for processing the diversity of specific immunoglobulins $[10,11]$. Thus, DNA ligase IV is an important protein which is essential for the development of a healthy immune system, as well as for the protection of genomic integrity. It is encoded in the LIG4 gene. Complete knock-out of the LIG4 gene in mice resulted in embryonic lethality $[12,13]$. This finding suggests that a null mutation might also be nonviable in human beings and explains why, until now, only hypomorphic mutations of the LIG4 gene have been described [11, 14]. Depending on the expression of the hypomorphic mutation, the immunologic phenotype ranges from $\mathrm{T}-\mathrm{B}-\mathrm{NK}+$ SCID ( $\mathrm{T}$ cell-negative ( $\mathrm{T}-$ ), B cell-negative (B-), natural killer cell-positive $(\mathrm{NK}+))$ to milder degrees of lymphopenia and hypogammaglobulinemia $[5,10,15]$. There are several other conditions with overlapping features such as Nijmegen breakage syndrome, Cernunnos-XLF deficiency, Fanconi anemia and Seckel syndrome [11].

The initial treatment aims to prevent life-threatening infections by administering antibiotic, antiviral and antifungal chemoprophylaxis, as well as transfusing immunoglobulins and blood (components) on a regular basis. Non-essential ionizing radiation should be avoided [11]. However, in severe cases with progressive bone marrow failure and the T-B-NK+ SCID phenotype this might not be sufficient. The risk of malignancy rises over time. HSCT could be a curative treatment option to prevent serious infections and deadly hematopoietic malignancies $[10,11]$.

In accordance with relevant current literature $[6,10$, 15-20], this report illustrates that HSCT in patients with DNA LIG4 deficiency can result in very different outcomes. The unique addition to these descriptions is that two brothers with the same underlying mutation received two different treatment protocols. While a rather mild conditioning regimen was successful in one brother, a rather more aggressive regimen failed in the other. Therefore, further studies are required to examine the role of different conditioning protocols and immunosuppressive treatments as well as the efficacy of this treatment option in ligase IV deficiency.

\section{Case presentation}

\section{Family medical history}

Three children were born to Caucasian, nonconsanguineous parents, who were in good health. There was no history of hereditary disorders in the family. The oldest child, a girl, was healthy and developed according to age.

\section{Case 1}

In June 2007, at the age of 2 years and 7 months, the older brother was referred to the hemato-oncological department of the University Children's Hospital Tuebingen. He presented with microcephaly and remarkable growth retardation (weight $10.3 \mathrm{~kg}$ ( $<3 \mathrm{rd}$ percentile), length $83 \mathrm{~cm}$ (<3rd percentile), head circumference 44 $\mathrm{cm}(<3$ rd percentile)). His skin appeared scaly, dry and rather pale; his hair was dry, brittle and scarce. Furthermore, the patient suffered from chronic bloody diarrhea, due to a persistent infection with norovirus. No neurological deficits were detected. The laboratory findings re-

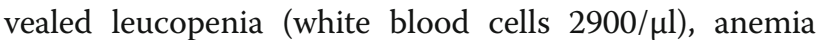
(hemoglobin $6.8 \mathrm{~g} / \mathrm{dl}$ ) and mild thrombocytopenia (thrombocytes $168,000 / \mu \mathrm{l}$ ). The number of lymphocytes $(484 / \mu \mathrm{l})$ was reduced, with CD3+ T cells on the lower limit $(282 / \mu \mathrm{l})$, no B cells $(\mathrm{CD} 19+1 / \mu \mathrm{l})$, sufficient CD4+ $\mathrm{T}$ cells $(214 / \mu \mathrm{l})$, remarkably few CD $8+\mathrm{T}$ cells $(34 / \mu \mathrm{l})$ and reduced CD16/56+ NK cells $(81 / \mu \mathrm{l})$. The immunoglobulin levels were within the normal range (IgG 924 $\mathrm{mg} / \mathrm{dl}$, IgA $112 \mathrm{mg} / \mathrm{dl}$, IgM $63 \mathrm{mg} / \mathrm{dl})$. The subclass analysis of IgG showed very low levels of IgG2 (IgG1 705 mg/dl, IgG2 43 mg/dl, IgG3 $24 \mathrm{mg} / \mathrm{dl}$, IgG4 < $7 \mathrm{mg} / \mathrm{dl})$. Conspicuously, the boy did not show adequate antibody titers after having received the standard vaccinations for his age. The first year of the boy's life had been unremarkable. But during his second year of life the patient suffered many viral and bacterial infections, mainly affecting the respiratory and the urinary tract. Cytomegalovirus (CMV) was detected several times in the urine and norovirus in the stool. There were several 
episodes of unclear fever. The boy had to be hospitalized multiple times due to severe infections and was treated with antibiotics eight times in 1 year. Furthermore the failure to thrive became obvious as well as a mild hepatomegaly. Several differential diagnoses such as cystic fibrosis, coeliac disease, gastrointestinal diseases or severe underlying infections such as hepatitis were ruled out in the previously treating hospital. As an immunodeficiency syndrome was suspected, he was treated with antibiotic chemoprophylaxis and intravenous immunoglobulins, starting when he first presented to the Children's Hospital Tuebingen. In order to identify the type of immunodeficiency syndrome a genetic analysis was performed in June 2007. At the age of 32 months the genetic findings revealed a DNA ligase IV deficiency, associated with SCID, with a compound heterozygous mutation in exon two of DNA LIG4 gene ((NM_002312) exon 2: c.613delT p.S205LfsX29 heterozygous and exon 2: c.845A > T p.H282L heterozygous). Both parents carry a heterozygous mutation (mother: ligase IV exon 2: c.845A > T p.H282L, heterozygous; father: ligase IV exon 2: c.613delT p.S205LfsX29 heterozygous). The sequencing of the RAG-1/2, Artemis, XLF and TCF3 genes did not show any abnormalities. In the chromosomal analysis a balanced translocation $(46, \mathrm{XY}, \mathrm{t}(1 ; 19)$ (q21; p13)) was found. The same karyotype could be detected in the healthy father. Thus, this chromosomal defect is considered an incidental finding.

In August 2007, at the age of 33 months, HSCT was performed due to the severity of the immunodeficiency. Conditioning was myeloablative with fludarabine $(4 \times 40$ $\left.\mathrm{mg} / \mathrm{m}^{2}\right)$, thiotepa $(1 \times 10 \mathrm{mg} / \mathrm{kg} \mathrm{BW})$, melphalan $(2 \times 70$ $\left.\mathrm{mg} / \mathrm{m}^{2}\right)$ and anti-thymocyte globulin $(10 \mathrm{mg} / \mathrm{kg} \mathrm{BW}$, divided $1 \times 1 \mathrm{mg} / \mathrm{kg} \mathrm{BW}, 3 \times 3 \mathrm{mg} / \mathrm{kg} \mathrm{BW})$. The boy suffered from severe mucositis during aplasia. He received $8.77 \times 10^{6} / \mathrm{kg} \mathrm{BW} \mathrm{CD34+} \mathrm{hematopoietic} \mathrm{progenitor} \mathrm{cells,}$ $1.524 \times 10^{7} / \mathrm{kg}$ BW CD3+ cells derived from the bone marrow of an HLA-identical (10/10 match), non-related female donor. The graft-versus-host disease (GvHD) prophylaxis was carried out with CSA (cyclosporine A 3 $\mathrm{mg} / \mathrm{kg}$ BW, target level $150-200 \mathrm{ng} / \mathrm{ml}$, day -1 until death on day +142 ), and methotrexate $10 \mathrm{mg} / \mathrm{m}^{2}$ (day + $1,+3,+6)$. Leukocyte and granulocyte take was observed at day +15 . In the following days, the child developed acute GvHD of the skin $\left(\mathrm{II}^{\circ}-\mathrm{III}^{\circ}\right.$, day +17$)$ which was initially treated locally with tacrolimus and glucocorticoids and then systemically with prednisolone (5 $\mathrm{mg} / \mathrm{kg} \mathrm{BW}$ ). After an initial improvement, the GvHD of the skin relapsed and was then treated with methylprednisolone $(5 \mathrm{mg} / \mathrm{kg} \mathrm{BW})$. A slow recovery was observed. Further complications, due to HSCT, were a foscavirassociated ulcer of the penis, CSA-associated hypertension, a reactivation of Epstein-Barr virus (EBV) and $\mathrm{CMV}$, as well as a possible candidemia (positive serology for Candida antigen in the peripheral blood three times) without any clinical symptoms. Treatment was changed from amphotericin B to caspofungin. Complete donor chimerism was observed 1 month after HSCT. On day + 32, 5690/ $\mu \mathrm{l} \mathrm{WBC,} \mathrm{1414/ \mu l} \mathrm{lymphocytes,}(960 / \mu \mathrm{l} \mathrm{CD3+,}$ 16/ $\mu \mathrm{l} \mathrm{CD19+,} \mathrm{189/ \mu l} \mathrm{CD4+,} \mathrm{752/ \mu l} \mathrm{CD8+,} \mathrm{291/ \mu l} \mathrm{CD16/}$ $56+$ ) were detected in the peripheral blood (Fig. 1).

A veno-occlusive disease (VOD) of the liver was diagnosed on day +58 and on day +74 the boy developed severe acute intestinal GvHD stadium IV, with bloody and watery diarrhea (stool volume $>1000 \mathrm{ml} / \mathrm{m}^{2}$ body surface area per day). The symptoms stabilized for a short time with high-dose methylprednisolone $(10 \mathrm{mg} / \mathrm{kg}$ BW per day, for 3 days), but then relapsed again. Further treatment consisted of somatostatin-infusions and symptomatic substitution of thrombocytes, erythrocytes, fresh frozen plasma (FFP) and coagulation factors. A causal immunosuppressive combination therapy, consisting of tacrolimus, steroids, CSA and infliximab was unable to stop the intestinal bleeding sufficiently. Furthermore the boy received $3.7 \times 10^{6} / \mathrm{kg}$ BW mesenchymal stem cells from his father as GvHD treatment. A colonoscopy showed necrosis and ulcers of the colonic mucosa with diffuse bleeding. A probable pulmonary aspergillosis was detected on day +105 . Aspergillus-galactomannan-antigen was positive (1.9 EIA, rising quickly to 4.8 EIA) and the computed tomography $(\mathrm{CT})$ scan showed intrapulmonary noduli suspected to be aspergillomas (Fig. 2a). Therefore, amphotericin B was added to the antifungal treatment with caspofungin. On day +135 , a severe intestinal bleeding, associated with intestinal GvHD, occurred (hemoglobin decreased from $14 \mathrm{~g} / \mathrm{dl}$ to $5 \mathrm{~g} / \mathrm{dl}$ ) and the patient was transferred to the intensive care unit (ICU) for massive transfusions of blood, thrombocytes, FFP and coagulation factors. He suffered from acute renal failure and transfusion-related acute lung injury. In combination with the aspergillosis, this led to an acute pulmonary hemorrhage and the need for mechanical ventilation.

Moreover, while being transferred to the ICU, the boy was already suffering from hemiparesis and somnolence. These neurological symptoms worsened and a magnetic resonance imaging (MRI) was conducted. The scan showed severe brain damage that could be associated with a cerebral aspergillosis (Fig. 2b) although Aspergillus antigen was not detected in the cerebrospinal fluid. On day +143 after HSCT, the patient succumbed to multiple organ failure. The autopsy report confirmed the suspected, invasive, cerebral aspergillosis (Fig. 2c, d).

\section{Case 2}

Another boy was born into the family in November 2006. Although this boy, 2 years younger than his brother, was hypotrophic at birth (weight $2.610 \mathrm{~kg}(<3 \mathrm{rd}$ 


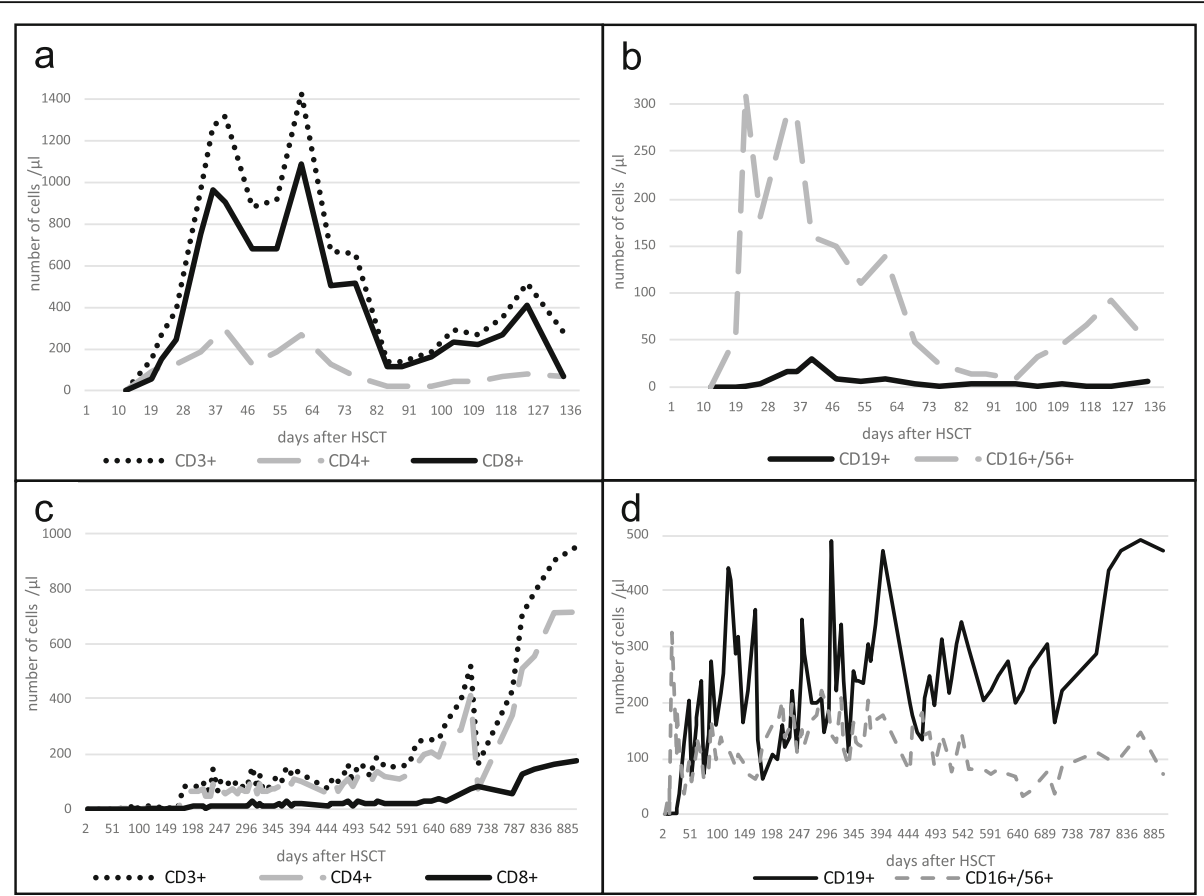

Fig. 1 Lymphocyte subsets by flow cytometry for T cells, B cells and NK cells after HSCT in both cases. a Development of T cells (CD3+, CD4+, CD8+) after HSCT in case 1, the number of T cells is decreasing over time. b Development of B cells (CD19), and NK cells (CD16+/56+) after HSCT in case 1, the number of B cells and NK cells is decreasing over time. c Development of T cells (CD3+, CD4+, CD8+) after HSCT in case 2. In contrast to case 1, the number of T cells is rising over time in case 2. $\mathbf{d}$ Development of B cells (CD19), and NK cells (CD16+/56+) after HSCT in case 2 . In contrast to case 1, the number of B cells and NK cells is rising over time in case 2. Standard values: CD3+ (800-1000/ $\mathrm{\mu l})$, CD4+ ( 400/ $\mu \mathrm{l}), \mathrm{CD} 8+(\sim 400 / \mu \mathrm{l}), \mathrm{CD} 19+(200-400 / \mu \mathrm{l}), \mathrm{CD} 16+/ 56+(\sim 200 / \mu \mathrm{l})$

percentile), length $49 \mathrm{~cm}$ (7th percentile), head circumference $33 \mathrm{~cm}(<3 \mathrm{rd}$ percentile)), the first 3 months of his life were uneventful. Subsequently, numerous pulmonary infections and chronic bronchitis with cough, pulmonary obstruction and secretion occurred. As with his brother, the laboratory findings revealed leucopenia

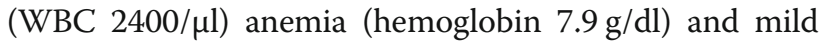
thrombocytopenia $(207,000 / \mu \mathrm{l})$. The number of lymphocytes was reduced $(245 / \mu \mathrm{l})$ with extremely reduced counts of B, T, and NK cells $(\mathrm{CD} 3+70 / \mu \mathrm{l}, \mathrm{CD} 19+2 / \mu \mathrm{l}$, $\mathrm{CD} 4+51 / \mu \mathrm{l}, \mathrm{CD} 8+13 / \mu \mathrm{l}, \mathrm{CD} 16 / 56+11 / \mu \mathrm{l})$. With the exception of $\operatorname{IgA}(<6 \mathrm{mg} / \mathrm{dl})$, the immunoglobulin levels were within the normal range (IgG $395 \mathrm{mg} / \mathrm{dl}$, IgM 46 $\mathrm{mg} / \mathrm{dl}$ ). The subclass analysis of IgG was normal (IgG1 $279 \mathrm{mg} / \mathrm{dl}, \mathrm{IgG} 263 \mathrm{mg} / \mathrm{dl}, \mathrm{IgG} 330 \mathrm{mg} / \mathrm{dl}, \mathrm{IgG} 4<7 \mathrm{mg} /$ dl). Similar to his older brother, the boy was treated with antibiotic, antifungal, and antiviral chemoprophylaxis and intravenous immunoglobulins. At the age of 8 months, the diagnosis of DNA ligase IV deficiency was confirmed genetically, at the same time as his brother was diagnosed. He carries the same compound heterozygous mutation in exon two of LIG4 gene (exon 2: c.613delT p.S205LfsX29 heterozygous and exon 2: c.845A > T p.H282L heterozygous) and the same karyotype $(46, \mathrm{XY}, \mathrm{t}(1 ; 19)(\mathrm{q} 21 ; \mathrm{p} 13))$.
At the age of 18 months, chronic, infiltrative changes in the lung structure were identified in the CT scan. Furthermore, there was a progressive bone marrow failure. Based on those findings, HSCT was performed. The treatment protocol was adapted because his brother had suffered from severe GvHD. This time, allogeneic HSCT was performed with a combination of dosage-reduced, myeloablative conditioning and $\mathrm{T}$ cell-depletion (CD3/ CD19 depletion) as well as CD34-selection. The chemotherapy consisted of fludarabine $\left(4 \times 40 \mathrm{mg} / \mathrm{m}^{2}\right)$, melphalan $\left(2 \times 60 \mathrm{mg} / \mathrm{m}^{2}\right)$ and anti-thymocyte globulin $(10$ $\mathrm{mg} / \mathrm{kg} \mathrm{BW}$, divided $1 \times 1 \mathrm{mg} / \mathrm{kg} \mathrm{BW}, 3 \times 3 \mathrm{mg} / \mathrm{kg} \mathrm{BW})$. Apart from a skin reaction with depigmentation, chemotherapy was tolerated well. There was no mucositis. The patient received $40 \times 10^{6} / \mathrm{kg} \mathrm{BW} \mathrm{CD} 34+$ hematopoietic progenitor cells and $1.62 \times 10^{4} / \mathrm{kg}$ BW CD3+ cells from a HLA-identical (10/10 matched), unrelated male donor. Besides the T cell-depletion no other GvHD prophylaxis was performed. Leukocyte and granulocyte take was observed at day +10 . On day +29 , complete chimerism

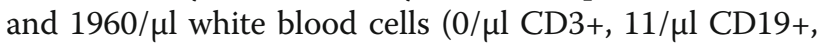
0/ $\mu \mathrm{l} \mathrm{CD} 4+, 0 / \mu \mathrm{l} \mathrm{CD} 8+, 189 / \mu \mathrm{l} \mathrm{CD16/56+)}$ were observed in the peripheral blood (Fig. 1c, d). There were no severe infections or GvHD post-transplant. About 6 months after the HSCT, the patient suffered from hemolytic 


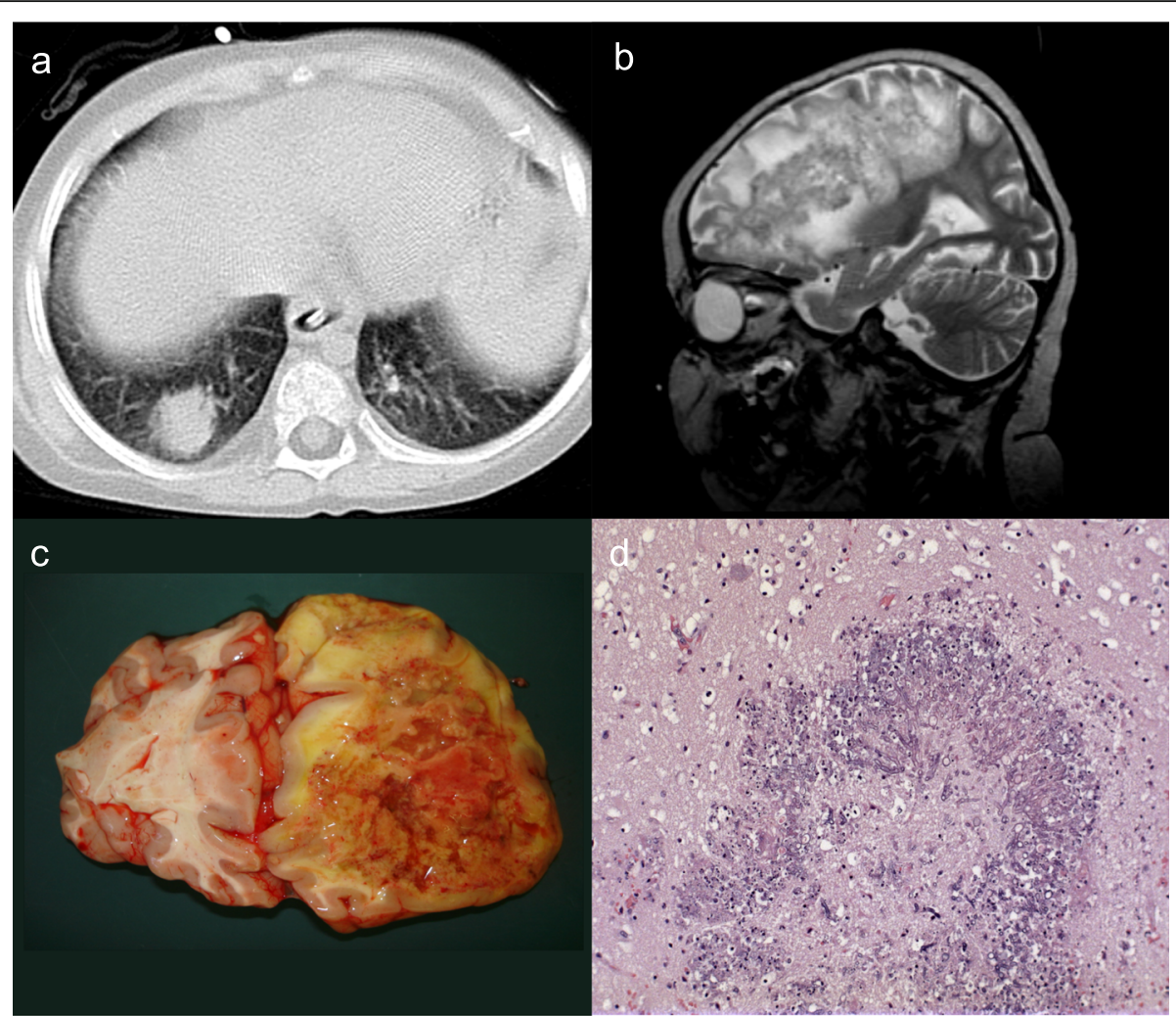

Fig. 2 Multifocal aspergillosis in case 1. a HRCT of the lung base demonstrates a large pulmonary nodule in the right lower lobe surrounded by a small halo. b Sagittal T2W MRI shows an overlap pattern of cerebritis and abscess within the right hemisphere. Note the multiple small hypointense foci which represent hemorrhages. c Neuropathological findings: macroscopic picture of the brain with a necrotizing brain abscess in the right frontal lobe, caused by aspergillosis. $\mathbf{d}$ Neuropathological findings: H\&E stain: histological brain tissue with central necrosis surrounded by yshaped hyphae, consistent with aspergillosis

uremic syndrome with acute renal failure, hypertension and edemas. The child developed a dilated cardiomyopathy due to hypertension. These symptoms were treated and disappeared during the following years. The cell count for $\mathrm{B}$ and $\mathrm{T}$ cells has normalized during the past couple of years (Fig. 1c, d), and the current $\mathrm{T}$ cell receptor repertoire, analyzed via $\mathrm{V} \alpha$ spectratype, shows a polyclonal diversity of $\mathrm{T}$ cell receptors reflecting a healthy immune competence (Fig. 3b). Today, the boy is 12 years old and is living a normal life. He attends a regular high school, plays sports and enjoys a good quality of life. At the 10-year follow up, he presented with extreme dwarfism and dystrophy (weight $14.1 \mathrm{~kg}(14.5 \mathrm{~kg}$ $<3 \mathrm{rd}$ percentile), length $110.8 \mathrm{~cm}(27 \mathrm{~cm}<3 \mathrm{rd}$ percentile) head circumference $45.1 \mathrm{~cm} \mathrm{(<3rd} \mathrm{percentile))} \mathrm{(Fig.} \mathrm{3a).}$ The bone age, calculated according to Greulich and Pyle [21], was in accordance with the chronological age. His maximum final adult height was calculated to be 135 $\mathrm{cm}$. The laboratory findings showed normal blood counts with hemoglobin $13.4 \mathrm{~g} / \mathrm{dl}$, thrombocytes 277 , $000 / \mu \mathrm{l}$ and WBC $9900 / \mu \mathrm{l}$ with $4059 / \mu \mathrm{l}$ lymphocytes

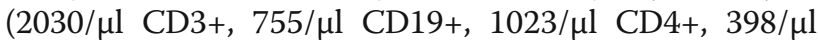
$\mathrm{CD} 8+, 321 / \mu \mathrm{l} \mathrm{CD16/56+).} \mathrm{Without} \mathrm{any} \mathrm{substitution} \mathrm{the}$ immunoglobulin levels were generally low, but for IgA and IgM within the normal range; only IgG remained below the standard value (IgG $411 \mathrm{mg} / \mathrm{dl}$, IgA $87 \mathrm{mg} / \mathrm{dl}$, IgM $63 \mathrm{mg} / \mathrm{dl}$ ) at the 10-year follow up. Complete donor chimerism was observed. The endocrinological findings revealed a hypergonadotropic hypogonadism (luteinizing hormone 6.4 IU/l (normal range: 1-3.5 IU/l), folliclestimulating hormone 64.4 IU/l (normal range: $<0.2-7.5$ IU/l)). The echocardiographic examination showed further improvement with very mild residuals of the dilated cardiomyopathy.

\section{Discussion and conclusions}

Generally there is a broad spectrum of clinical manifestation associated with LIG4 deficiency. The compound heterozygous mutations (c.613delT, c.845A $>\mathrm{T}$ ) in both brothers are not among the most common in ligase IV deficiency but have been mentioned before individually $[3,7,16,17]$. However, no combination of the two variants in one patient has been mentioned in the literature before. Considering the classification of the American College of Medical Genetics and Genomics an the Association for Molecular Pathology [22] the mutation 


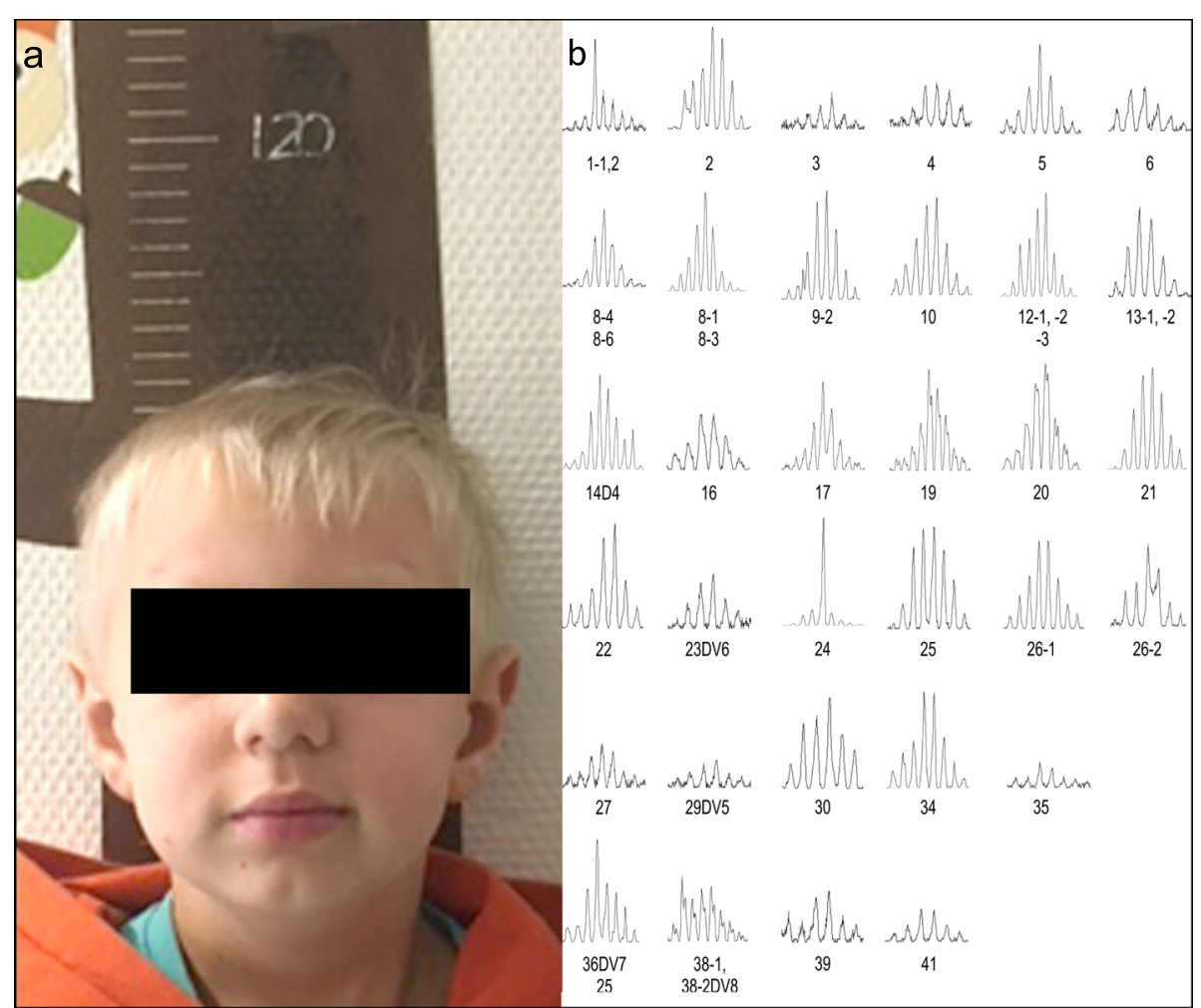

Fig. 3 Follow-up 10 years after HSCT. a Picture of the boy, 10 years after HSCT: bird-like face with sloping forehead, micrognathia, long nose, microcephaly (head circumference $45.1 \mathrm{~cm}(<3 \mathrm{rd}$ percentile)) and dwarfism (length $110.8 \mathrm{~cm}(27 \mathrm{~cm}(<3 \mathrm{rd}$ percentile)). b Spectratype analysis of TCR Va repertoire of peripheral T cells. Assessment of T cell receptor diversity for monitoring immune reconstitution post-hematopoietic stem cell transplantation in case 2. The spectratype analysis shows a complete, unbiased and broad based repertoire indicating a maximum of TCR diversity, conferring immune competence

c.613delT has to be classified as 'pathogenic'. It results in a frameshift and a premature stop codon in the DNAbinding domain (p.S205LfsX29). This mutation is described in the literature in two patients with ligase IV deficiency and in a patient presenting with Dubowitz syndrome $[3,23,24]$. The missense variant c.845A $>\mathrm{T}$ inherited by the mother is graded as 'likely pathogenic'. The reference transcript p.H282L has been described in patients receiving HSCT (Table 1).

There is no established genotype-phenotype correlation. The disease severity is assumed to be associated with the residual activity of ligase IV, but influenced by the DNA repair mechanisms [8]. In general biallelic truncating mutations are associated with a more severe phenotype than compound-heterozygous localization of a missense and a truncating variant [3]. The combination of different variants can be classified in genotype 1 (two truncating mutations) and genotype 2 (truncating mutation and missense mutation) with different immunoglobulin levels. Genotype 2 is associated with a mild to moderate ligase IV deficiency [7]. Patients carrying missense mutations show remarkably reduced function of the ligase IV [11]. p.H282L leads to a residual ligase IV enzyme activity of 5 to $10 \%$ [25]. The paternal mutation (c.613delT p.S205LfsX29) is associated with a severe form of ligase IV deficiency, characterized by early mortality and SCID. This can be explained by the correlation between the location of truncating LIG4 variants and the severity of the resulting phenotype in patients with two truncating variants studied by Murray et al. A late truncating mutation is associated with rather mild symptoms, whereas early truncating mutations such as p.S205LfsX29 are associated with a severe growth retardation and immunodeficiency [3]. In one report, the authors even concluded that this mutation might result in a null mutation because of the lack of a nuclear localization signal [23]. These observations are consistent with the presented case of a severe type of ligase IV deficiency with major infections and high mortality. In contrast, an intrafamilial variability of the phenotype was demonstrated in two unrelated families in siblings carrying genotype $2[5,16]$. In addition two patients from another study with the same genotype 2 displayed slightly variable phenotypes and one of them developed non-Hodgkin lymphoma [2]. Thus there might be additional factors influencing the manifestation 
Table 1 Summary of the literature. Conditioning regimen, GvHD prophylaxes, mutations and outcome of the published case reports of HSCT in patients with ligase IV deficiency

\begin{tabular}{|c|c|c|c|c|c|}
\hline patient & conditioning regimen & GvHD prophylaxes & outcome & mutation & ref. \\
\hline $\begin{array}{l}\text { girl, } 2 \\
\text { months }\end{array}$ & N/A & N/A & $\begin{array}{l}\text { died } 2 \text { months after HSCT } \\
\text { due to VOD }\end{array}$ & $\begin{array}{l}\text { c.1544_1548del5bp } \\
\text { (p.K424fs20X), c.1112A> } \\
\text { G (p.Q280R) }\end{array}$ & {$[18]$} \\
\hline $\begin{array}{l}\text { girl, } 19 \\
\text { months }\end{array}$ & $\mathrm{N} / \mathrm{A}$ & N/A & $\begin{array}{l}\text { died due to EBV-associated } \\
\text { lymphoproliferative syn- } \\
\text { drome on day }+50\end{array}$ & $\begin{array}{l}\text { c.1544_1548del5bp } \\
\text { (p.K424fs20X), c.1112A > } \\
\text { G (p.Q280R) }\end{array}$ & [18] \\
\hline $\begin{array}{l}\text { girl, } 11 \\
\text { years }\end{array}$ & $\begin{array}{l}\text { fludarabine }\left(4 \times 30 \mathrm{mg} / \mathrm{m}^{2}\right) \text {, cyclophosphamide } \\
(4 \times 10 \mathrm{mg} / \mathrm{kg}) \text {, anti-thymocyte globulin }(4 \times 15 \\
\mathrm{mg} / \mathrm{kg})\end{array}$ & cyclosporine A & survived & $\begin{array}{l}\text { c.1406G > A (p.G469E), } \\
\text { c.2440C > T (p.R814X) }\end{array}$ & [10] \\
\hline $\begin{array}{l}\text { girl, } 10 \\
\text { years }\end{array}$ & $\begin{array}{l}\text { fludarabine }\left(5 \times 35 \mathrm{mg} / \mathrm{m}^{2}\right) \text {, cyclophosphamide } \\
(4 \times 10 \mathrm{mg} / \mathrm{kg}) \text {, anti-thymocyte globulin }\end{array}$ & cyclosporine A & $\begin{array}{l}\text { survived, autologous } \\
\text { reconstitution, day }+23\end{array}$ & $\begin{array}{l}\text { c.1762delAAG } \\
\text { (p.K588del), homozygous }\end{array}$ & [19] \\
\hline $\begin{array}{l}\text { same } \\
\text { girl, } 10 \\
\text { years }\end{array}$ & $\begin{array}{l}\text { busulfan }(4 \times 2 \mathrm{mg} / \mathrm{kg}) \text {, cyclophosphamide }(3 \times \\
50 \mathrm{mg} / \mathrm{kg}) \text {, anti-thymocyte globulin }\end{array}$ & $\begin{array}{l}\text { methotrexate, } \\
\text { cyclosporine A }\end{array}$ & survived & $\begin{array}{l}\text { c.1762delAAG } \\
\text { (p.K588del), homozygous }\end{array}$ & [19] \\
\hline $\begin{array}{l}\text { girl, } 4 \\
\text { months }\end{array}$ & fludarabine, thiotepa & cyclosporine A & survived & $\begin{array}{l}\text { c.1118A > T (p.H282L), } \\
\text { c.1544_1548delAAAGA } \\
\text { (p.D423fs442X) }\end{array}$ & [16] \\
\hline $\begin{array}{l}\text { girl, } 2 \\
\text { years }\end{array}$ & N/A & N/A & $\begin{array}{l}\text { died during preparative } \\
\text { therapy for HSCT }\end{array}$ & $\begin{array}{l}\text { c.1118A > T (p.H282L), } \\
\text { c.1544_1548delAAAGA } \\
\text { (p.D423fs442X) }\end{array}$ & [16] \\
\hline $\begin{array}{l}\text { girl, } 6 \\
\text { months }\end{array}$ & $\begin{array}{l}\text { busulfan }(4 \times 16 \mathrm{mg} / \mathrm{kg}) \text {, cyclophosphamide, } \\
(4 \times 200 \mathrm{mg} / \mathrm{kg})\end{array}$ & $\begin{array}{l}\text { cyclosporine A, } \\
\text { methylprednisolone, } \\
\text { mycophenolat mofetil }\end{array}$ & survived & $\begin{array}{l}\text { c.845A }>\text { T (p.H282L), } \\
\text { c.1747_1751del5bp } \\
\text { (p.R581fsX) }\end{array}$ & [17] \\
\hline $\begin{array}{l}\text { girl, } \sim \\
2 \text { years }\end{array}$ & $\begin{array}{l}\text { busulfan ( } 4 \times 50 \mathrm{mg}) \text {, cyclophosphamide, }(4 \times \\
500 \mathrm{mg})\end{array}$ & N/A & $\begin{array}{l}\text { died due to bradycardia and } \\
\text { respiratory arrest }\end{array}$ & $\begin{array}{l}\text { g.5333_5335delCAA } \\
\text { (p.Q433del), homozygous }\end{array}$ & [15] \\
\hline $\begin{array}{l}\text { boy, } 4 \\
\text { years }\end{array}$ & $\begin{array}{l}\text { alemtuzumab }(3 \times 0,3 \mathrm{mg} / \mathrm{kg}) \text {, anti CD } 45(4 \times 0,4 \\
\mathrm{mg} / \mathrm{kg}) \text {, fludarabine }(5 \times 30 \mathrm{mg} / \mathrm{kg}) \\
\text { cyclophosphamide } \\
\left(4 \times 300 \mathrm{mg} / \mathrm{m}^{2}\right)\end{array}$ & $\begin{array}{l}\text { cyclosporine } A, \\
\text { mycophenolat mofetil }\end{array}$ & survived & N/A & [20] \\
\hline $\begin{array}{l}\text { girl, } 19 \\
\text { months }\end{array}$ & $\begin{array}{l}\text { cyclophosphamide (10 mg/kg), fludarabine ( } 30 \\
\left.\mathrm{mg} / \mathrm{m}^{2}\right) \text {, anti-thymocyte globulin }(15 \mathrm{mg} / \mathrm{kg})\end{array}$ & $\begin{array}{l}\text { cyclosporine A, } \\
\text { prednisolone }\end{array}$ & $\begin{array}{l}\text { died due to toxic epidermal } \\
\text { necrolysis and fungal } \\
\text { infection }\end{array}$ & c.1904delA, c.907G > C & [6] \\
\hline $\begin{array}{l}\text { boy, } \\
33 \\
\text { months }\end{array}$ & $\begin{array}{l}\text { fludarabine }\left(4 \times 40 \mathrm{mg} / \mathrm{m}^{2}\right) \text {, thiotepa }(1 \times 10 \\
\mathrm{mg} / \mathrm{kg}) \text {, melphalan }\left(2 \times 70 \mathrm{mg} / \mathrm{m}^{2}\right) \text {, anti- } \\
\text { thymocyte globulin }(10 \mathrm{mg} / \mathrm{kg})\end{array}$ & $\begin{array}{l}\text { cyclosporine } \mathrm{A}, \\
\text { prednisolone, } \\
\text { methotrexate }\end{array}$ & died due to aspergillosis & $\begin{array}{l}\text { c.845A > T (p.H282L), } \\
\text { c.613delT (p.S205LfSX29) }\end{array}$ & $\begin{array}{l}\text { this } \\
\text { case }\end{array}$ \\
\hline $\begin{array}{l}\text { boy, } \\
18 \\
\text { months }\end{array}$ & $\begin{array}{l}\text { fludarabine }\left(4 \times 40 \mathrm{mg} / \mathrm{m}^{2}\right) \text {, melphalan }(2 \times 60 \\
\left.\mathrm{mg} / \mathrm{m}^{2}\right) \text {, anti-thymocyte globulin }(10 \mathrm{mg} / \mathrm{kg})\end{array}$ & $\begin{array}{l}\text { T cell-depletion (CD3/ } \\
\text { CD19 depletion) }\end{array}$ & survived & $\begin{array}{l}\text { c.845A > T (p.H282L), } \\
\text { c.613delT (p.S205LfSX29) }\end{array}$ & $\begin{array}{l}\text { this } \\
\text { case }\end{array}$ \\
\hline
\end{tabular}

Abbreviations: N/A Not applicable

and severity in the phenotype of ligase IV deficiency. For instance there is a report on a somatic reversion of germline LIG4 variant in some clones of blood cell lines detected in one patient with LIG4 deficiency [2].

To date, no curative treatment option exists. However, HSCT has been proposed as a therapy option [11]. By transplanting a new immune system, the risk of lifethreatening infections and malignancies can be reduced, as well as the need for transfusions. Other symptoms such as microcephaly, growth retardation, "bird-like" face or developmental and mental delay are not affected by HSCT [17].

In the presented case, only one of the two brothers survived HSCT. High mortality in this particular group of patients is consistent with current literature. There are 11 published case reports of HSCT in DNA ligase IV deficiency [6, 9-11, 15-20, 26]. Out of these cases, six survived HSCT and five died due to severe side-effects of the conditioning regimen (Table 1). The older brother's diagnosis was unknown for a long time, resulting in late referral into a specialized unit. Consequently HSCT was performed rather late (33 months), compared to the published cases (median 24 months, range 2-132 months). Based on the limited number of reported cases involving various mutations no correlation between position of mutation and outcome after HSCT can be derived.

As there was no HLA-identical family donor, the two brothers received HSCT from a matched unrelated donor (MUD). A retrospective analysis of HSCT in 94 
SCID-patients concluded that if there was no HLAidentical family donor, a MUD would be the best option. There might be a better engraftment, reconstitution, quality of life and overall survival, when using a graft from a MUD compared to a mismatched related donor [17, 27, 28].

The conditioning regimen is especially important in patients with DNA ligase IV deficiency, because there is increased toxicity in patients suffering from DNA repair disorders. Thus, chemotherapy-based conditioning is poorly tolerated and may result in transplant-related morbidity and mortality [20]. To date, there is no recognized standard conditioning regimen of HSCT in patients with DNA ligase IV deficiency. A review of published case reports, indicates that several chemotherapy regimens have been administered, either myeloablative or in reduced intensity $[6,10,15-17,19,20,29]$. A summary of the published literature is displayed in Table 1.

The regimen of the older brother has been used in another case as well. This patient survived HSCT, but suffered from severe hemolytic-uremic syndrome [16]. Furthermore, a reduced-intensity conditioning regimen consisting of fludarabine $\left(4 \times 30 \mathrm{mg} / \mathrm{m}^{2}\right)$, cyclophosphamide $(4 \times 10 \mathrm{mg} / \mathrm{kg} \mathrm{BW})$ and anti-thymocyte globulin $(4 \times 15 \mathrm{mg} / \mathrm{kg} \mathrm{BW})$ is described. One patient went through this mild regimen without major problems [10]. Another patient died 1 month post-transplant, due to toxic epidermal necrolysis and fungal respiratory infection [6]. If the conditioning regimen is too mild, the risk of autologous reconstitution will increase. This effect was observed in one patient who received the same, intensity-reduced conditioning regimen. The patient subsequently underwent a second HSCT with chemotherapy consisting of busulfan, cyclophosphamide and anti-thymocyte globulin. This time, the transplantation was successful [19]. The myeloablative combination of busulfan and cyclophsphamid has been applied in another HSCT successfully [17]. In contrast, an 18months-old girl died due to bradycardia and respiratory arrest during the conditioning process, consisting of the same regimen [15]. Generally, there are different approaches to modify the conditioning regimen. An antibody-based minimal-intensity conditioning regimen consisting of anti-CD45 monoclonal antibodies, alemtuzumab (anti-CD52), fludarabine and low-dose cyclophosphamide is described. Out of 16 high-risk patients treated by this combination $81 \%$ survived and were cured [20].

\section{Review of the published case reports of HSCT in ligase IV deficiency}

Due to the rarity of DNA ligase IV deficiency and the limited number of patients undergoing HSCT, there is no general recommendation as to which conditioning protocol should be followed. Because of the severe radiosensitivity, irradiation should not be part of the conditioning regimen $[11,19]$. Patients with defects in NHEJ suffer from an increased sensitivity to alkylating agents. For best survival and minimal late effects, it is suggested to minimize the exposure to alkylating agents. In accordance with our report, myeloablative conditioning does not seem to be necessary for performing HSCT successfully. On the contrary, myeloablative conditioning regimens are associated with a higher mortality and morbidity compared to reduced intensity conditioning regimens $[29,30]$. In the future, transplantation of genecorrected autologous CD34+ cells might simplify the conditioning regimen [31].

Another major difference between the two cases is the GvHD prophylaxis. In the first case, the prophylaxis was carried out with CSA (cyclosporine A, day - 1 until death) and methotrexate $10 \mathrm{mg} / \mathrm{m}^{2}$ (day $\left.+1,+3,+6\right)$. In contrast, there was no GvHD prophylaxis apart from CD3/ CD19 depletion and anti-thymocyte globulin in the second case. In an experimental in vitro study, it was shown that CSA can induce double-strand breaks in cells with DNA ligase IV deficiency. Furthermore, double-strand breaks particularly occurred in busulfan and fludarabine pre-treated DNA LIG4 deficient cells [32]. Fludarabine was part of the chemotherapy in the first case. Moreover the dosage of CSA $(3 \mathrm{mg} / \mathrm{kg})$ was rather low in successfully transplanted cases $[10,19]$. The role of CSA in HSCT in patients with DNA LIG4 deficiency has still to be determined in further studies, but it might have a negative impact on the outcome in this selected group of patients inducing double-strand breaks.

In the 10-year follow up, the younger brother was in good shape, except for the ligase IV deficiency-related dwarfism and dystrophy. A fully recovered immune system, was confirmed by Va spectratype (Fig. 3b). Hypergonadotropic hypogonadism was an unexpected finding. To the authors' knowledge, there is no proven association between ligase VI deficiency and hypergonadotropic hypogonadism. But there are four descriptions of hypogonadism in LIG4 deficiency patients [3, 9, 11, 19]. Further investigation is needed to clarify if there are some endocrinological disorders associated with LIG4 deficiency. Thus, the cause of this endocrinological problem in the boy remains unknown. The laboratory findings indicate a primary testicular damage. One might speculate that it could also be related to HSCT's toxicity, or to the late orchidopexy, which was performed at the age of 4 years.

The data presented in this case report does not allow any generalization concerning treatment recommendations or cause-effect relationships as this is a retrospective description of two patients with a rare genetic disease. The strength of this case can be found in the fact that two brothers sharing the same genetic background and who 
are suffering from an identical mutation are treated with different HSCT regimen resulting in vastly different outcomes with one brother dying and the other one - receiving a milder regimen - fully recovering. Therefore further studies to carefully evaluate the efficacy of HSCT as a treatment option, as well as the conditioning regimen and GvHD prophylaxes in patients with DNA ligase IV deficiency are required.

\begin{abstract}
Abbreviations
BW: Bodyweight; CMV: Cytomegalovirus; CSA: Cyclosporine A; CT: Computed tomography; DNA: Deoxyribonucleic acid; EBV: Epstein-Barr virus; FFP: Fresh frozen plasma; GvHD: Graft-versus-host disease; HSCT: Hematopoietic stem cell transplantation; ICU: Intensive care unit; LIG4: DNA ligase IV; MRI: Magnetic resonance imaging; MUD: Matched unrelated donor; NHEJ: Nonhomologous end-joining; SCID: Severe combined immunodeficiency; TCR: T cell receptor; VOD: Veno-occlusive disease; WBC: White blood cells: XLF: XRCC4-like factor
\end{abstract}

\section{Acknowledgements}

Not applicable.

\section{Authors' contributions}

SS gathered and analyzed the data and wrote the entire article. MD and RH concepted and supervised the project and have made significant contributions to the interpretation of the data and revision of the manuscript. KS, JFS, JS and PK substantially contributed to the data acquisition, analysis and interpretation. $\mathrm{KCS}, \mathrm{UH}, \mathrm{IM}$ and $\mathrm{PL}$ were involved in data acquisition and interpretation, and were major contributors to drafting and/or revising the manuscript. All authors read and approved the submitted version of the manuscript and have agreed both to be personally accountable for the author's own contributions and to ensure that questions related to the accuracy or integrity of any part of the work, even ones in which the author was not personally involved, are appropriately investigated resolved, and the resolution documented in the literature.

\section{Funding}

There was no funding of the presented study.

\section{Availability of data and materials}

The datasets used and/or analyzed in the current study are available from the corresponding author on reasonable request.

\section{Ethics approval and consent to participate}

Written informed consent was obtained from the patients' parents for publication of this case report and any accompanying images. A copy of the written consent is available for review by the Editor-in-Chief of this journal. The retrospective data acquisition was approved by the local ethics committee of the University Hospital and the Eberhard-Karls University Tuebingen (Re-No. 578/2018A).

\section{Consent for publication}

Written informed consent for publication was obtained by the parents of the two patients. A copy of the written consent is available for review by the Editor-in-Chief of this journal.

\section{Competing interests}

The authors declare that they have no competing interests.

\section{Author details}

${ }^{1}$ Department I - General Pediatrics, Hematology/Oncology, University Children's Hospital Tuebingen, Hoppe-Seyler-Str.1, 72076 Tuebingen, Germany. ${ }^{2}$ Department of Neuropathology, Institute of Pathology and Neuropathology, Eberhard-Karls University Tuebingen, Calwer Str. 3, 72074 Tuebingen, Germany. ${ }^{3}$ Department of Diagnostic and Interventional Radiology, University Hospital Tuebingen, Hoppe-Seyler-Str. 3, 72076 Tuebingen, Germany. ${ }^{4}$ Division for Pediatric Stem Cell Transplantation and Immunology, Clinic for Pediatric Hematology and Oncology, University
Medical Center Hamburg-Eppendorf, Martinistr, 52, 20246 Hamburg, Germany.

Received: 5 July 2019 Accepted: 16 September 2019

Published online: 11 October 2019

\section{References}

1. Riballo E, Critchlow SE, Teo SH, Doherty AJ, Priestley A, Broughton B, et al. Identification of a defect in DNA ligase IV in a radiosensitive leukaemia patient. Curr Biol. 1999;9(13):699-702.

2. Jiang J, Tang W, An Y, Tang M, Wu J, Qin T, et al. Molecular and immunological characterization of DNA ligase IV deficiency. Clin Immunol. 2016;163:75-83.

3. Murray JE, Bicknell LS, Yigit G, Duker AL, van Kogelenberg M, Haghayegh S, et al. Extreme growth failure is a common presentation of ligase IV deficiency. Hum Mutat. 2014;35(1):76-85.

4. Fadda A, Butt F, Tomei S, Deola S, Lo B, Robay A, et al. Two hits in one: whole genome sequencing unveils LIG4 syndrome and urofacial syndrome in a case report of a child with complex phenotype. BMC Med Genet. 2016; 17(1):84.

5. Felgentreff K, Baxi SN, Lee YN, Dobbs K, Henderson LA, Csomos K, et al. Ligase-4 deficiency causes distinctive immune abnormalities in asymptomatic individuals. J Clin Immunol. 2016;36(4):341-53.

6. Brunet BA, Dave N. Unique heterozygous presentation in an infant with DNA ligase IV syndrome. Ann Allergy Asthma Immunol. 2017;119(4):379-80.

7. Dard R, Herve B, Leblanc T, de Villartay JP, Collopy L, Vulliami T, et al. DNA ligase IV deficiency: immunoglobulin class deficiency depends on the genotype. Pediatr Allergy Immunol. 2017;28(3):298-303.

8. Staines Boone AT, Chinn IK, Alaez-Verson C, Yamazaki-Nakashimada MA, Carrillo-Sanchez K, Garcia-Cruz MLH, et al. Failing to make ends meet: the broad clinical Spectrum of DNA ligase IV deficiency. Case series and review of the literature. Front Pediatr. 2018:6:426.

9. O'Driscoll M, Cerosaletti KM, Girard PM, Dai Y, Stumm M, Kysela B, et al. DNA ligase IV mutations identified in patients exhibiting developmental delay and immunodeficiency. Mol Cell. 2001:8(6):1175-85.

10. Gruhn B, Seidel J, Zintl F, Varon R, Tonnies H, Neitzel H, et al. Successful bone marrow transplantation in a patient with DNA ligase IV deficiency and bone marrow failure. Orphanet J Rare Dis. 2007;2:5

11. Altmann T, Gennery AR. DNA ligase IV syndrome; a review. Orphanet J Rare Dis. 2016;11(1):137

12. Barnes DE, Stamp G, Rosewell I, Denzel A, Lindahl T. Targeted disruption of the gene encoding DNA ligase IV leads to lethality in embryonic mice. Curr Biol. 1998;8(25):1395-8.

13. Frank KM, Sekiguchi JM, Seidl KJ, Swat W, Rathbun GA, Cheng HL, et al. Late embryonic lethality and impaired $V(D) J$ recombination in mice lacking DNA ligase IV. Nature. 1998;396(6707):173-7.

14. Buck D, Malivert $L$, de Chasseval R, Barraud A, Fondaneche MC, Sanal O, et al. Cernunnos, a novel nonhomologous end-joining factor, is mutated in human immunodeficiency with microcephaly. Cell. 2006;124(2):287-99.

15. van der Burg $M$, van Veelen LR, Verkaik NS, Wiegant WW, Hartwig NG, Barendregt $\mathrm{BH}$, et al. A new type of radiosensitive T-B-NK+ severe combined immunodeficiency caused by a LIG4 mutation. J Clin Invest. 2006;116(1):137-45.

16. Enders A, Fisch P, Schwarz K, Duffner U, Pannicke U, Nikolopoulos E, et al. A severe form of human combined immunodeficiency due to mutations in DNA ligase IV. J Immunol. 2006:176(8):5060-8.

17. Grunebaum E, Bates A, Roifman CM. Omenn syndrome is associated with mutations in DNA ligase IV. J Allergy Clin Immunol. 2008;122(6):1219-20.

18. Buck D, Moshous D, de Chasseval R, Ma Y, le Deist F, Cavazzana-Calvo $M$, et al. Severe combined immunodeficiency and microcephaly in siblings with hypomorphic mutations in DNA ligase IV. Eur J Immunol. 2006;36(1):224-35.

19. Unal S, Cerosaletti K, Uckan-Cetinkaya D, Cetin M, Gumruk F. A novel mutation in a family with DNA ligase IV deficiency syndrome. Pediatr Blood Cancer. 2009:53(3):482-4.

20. Straathof KC, Rao K, Eyrich M, Hale G, Bird P, Berrie E, et al. Haemopoietic stem-cell transplantation with antibody-based minimal-intensity conditioning: a phase 1/2 study. Lancet. 2009;374(9693):912-20.

21. Greulich WW, Pyle SI. Radiographic atlas of skeletal development of the hand and wrist. Am J Med Sci. 1959;238:393. 
22. Richards S, Aziz N, Bale S, Bick D, Das S, Gastier-Foster J, et al. Standards and guidelines for the interpretation of sequence variants: a joint consensus recommendation of the American College of Medical Genetics and Genomics and the Association for Molecular Pathology. Genet Med. 2015 17(5):405-24.

23. IJ H, Warris A, van der Flier M, Reisli I, Keles S, Chishimba S, et al. Clinical spectrum of LIG4 deficiency is broadened with severe dysmaturity, primordial dwarfism, and neurological abnormalities. Hum Mutat. 2013; 34(12):1611-4.

24. Aad G, Abbott B, Abdallah J, Abdinov O, Aben R, Abolins M, et al. Determination of the ratio of b-quark fragmentation fractions $\mathrm{f}(\mathrm{s}) / \mathrm{f}(\mathrm{d})$ in $\mathrm{pp}$ collisions at radicals=7 TeV with the ATLAS detector. Phys Rev Lett. 2015; 115(26):262001.

25. Chistiakov DA, Voronova NV, Chistiakov AP. Ligase IV syndrome. Eur J Med Genet. 2009;52(6):373-8.

26. O'Driscoll M, Gennery AR, Seidel J, Concannon P, Jeggo PA. An overview of three new disorders associated with genetic instability: LIG4 syndrome, RSSCID and ATR-Seckel syndrome. DNA Repair (Amst). 2004;3(8-9):1227-35.

27. Roifman CM, Grunebaum E, Dalal I, Notarangelo L. Matched unrelated bone marrow transplant for severe combined immunodeficiency. Immunol Res. 2007;38(1-3):191-200.

28. Dalal I, Reid B, Doyle J, Freedman M, Calderwood S, Saunders F, et al. Matched unrelated bone marrow transplantation for combined immunodeficiency. Bone Marrow Transplant. 2000;25(6):613-21.

29. Cowan MJ, Gennery AR. Radiation-sensitive severe combined immunodeficiency: the arguments for and against conditioning before hematopoietic cell transplantation--what to do? J Allergy Clin Immunol. 2015;136(5):1178-85

30. Slack J, Albert MH, Balashov D, Belohradsky BH, Bertaina A, Bleesing J, et al. Outcome of hematopoietic cell transplantation for DNA double-strand break repair disorders. J Allergy Clin Immunol. 2018;141(1):322-8 e10.

31. Aad G, Abbott B, Abdallah J, Abdel Khalek S, Abdinov O, Aben R, et al. Twoparticle Bose-Einstein correlations in pp collisions at [Formula: see text] 0.9 and $7 \mathrm{TeV}$ measured with the ATLAS detector. Eur Phys J C Part Fields. 2015;75(10):466.

32. O'Driscoll M, Jeggo PA. CSA can induce DNA double-strand breaks: implications for BMT regimens particularly for individuals with defective DNA repair. Bone Marrow Transplant. 2008;41(11):983-9.

\section{Publisher's Note}

Springer Nature remains neutral with regard to jurisdictional claims in published maps and institutional affiliations.

Ready to submit your research? Choose BMC and benefit from:

- fast, convenient online submission

- thorough peer review by experienced researchers in your field

- rapid publication on acceptance

- support for research data, including large and complex data types

- gold Open Access which fosters wider collaboration and increased citations

- maximum visibility for your research: over $100 \mathrm{M}$ website views per year

At $\mathrm{BMC}$, research is always in progress.

Learn more biomedcentral.com/submissions 